\title{
PARASITIC EGGS, CYSTS AND LARVAE OF SOME FRUITS SOLD AROUND DUTSIN-MA METROPOLIS, KATSINA STATE, NIGERIA
}

\author{
Orpin, J. B, Mzungu. I, Usman-Sani, H
}

Federal University Dutsin-Ma, PMB 5001, Dutsin-Ma, Katsina State, Nigeria

Corresponding Author's email: jorpin@fudutsinma.edu.ng +2348036854908

\begin{abstract}
Several parasitic infections are associated with poor personal hygiene and environmental sanitation resulting in fruits containing eggs, cysts or larva of parasites. A survey of some fruits sold around Dutsin-ma metropolis in Katsina was carried out to identify the eggs, cyst and larva present on them. A total of 180 fruit pieces were examined using standard wet mount procedure and Kinyoun acid fast stain to detect presence of parasites. The percentage of fruits found with eggs, cysts or larvae of six parasites identified were eggs of hookworm (16.42\%), Ascaris lumbricoides eggs (24.30\%), Trichuris trichuira eggs (8.62\%), Strongyloides stercoralis larvae (6.64\%), immature cyst of Entamoeba histolytica (31.62\%) and eggs of Taenia species (12.4\%) respectively. Garden eggs had the highest percentage with parasites' ova, cysts or larva $(60.3 \%)$ followed by water melon $(21.4 \%)$ and cucumber $(12.12 \%)$, mangoes $(10 \%)$, carrots $(4.8 \%)$ and oranges $(0 \%)$. The chi-square test showed significant $(\mathrm{p}<0.05)$ differences in number of fruits with parasitic infection. It is very important to encourage proper washing of fresh and raw fruits before they are sold or eaten which will thereby prevent transmission either at point of sell or consumption of fruits which infect via the oral route.
\end{abstract}

Keywords: Parasitic, Eggs, Cysts, Larvae, Fruits.

\section{INTRODUCTION}

Fruits are a part of diet for man and an important component of a healthy diet because they contain essential vitamins necessary for growth and body nourishment (Carey et al 1996). Raw fruits are known to be the major source for transmission of soil-transmitted helminthiasis (STH) when consumed without proper washing (Uneke, 2007). Intestinal parasitic infection is becoming an increasing concern because of the expanding number of individuals at risk of infection, particularly children, pregnant women, elderly and the immune-compromised persons (Erdogurul and Sener, 2005). Intestinal parasitic infection may be acquired in different ways including consumption of contaminated fruits, vegetables, other food stuff, and water (Al-Binali et al., 2006). The extent of the occurrence of parasitic eggs, cysts and larva on fruits depends on several factors that include the handling of untreated wastewater, poor personal hygiene, poor sanitation, and the use of faecal matter as fertilizer on the farm (Amoah et al., 2007). Faeces harbour helminth and protozoa eggs, cysts and larvae, according to Thaddeus et al. (2005), Amoah, (2009) and Hassan et al. (2013) farmers do not allow the faeces to decompose very well before application on the farm.

Soil-transmitted helminth infection is endemic in many areas of the world, principally in developing countries with poor environmental sanitation and personal hygiene (Naish et al., 2004). The mode of transmission is usually faeco-oral and there is high prevalence among people who live in areas with indiscriminate contamination of soil with human faeces, where sanitary facilities are inadequate. STI infection is mainly established by oral intake of infective eggs and, or cysts from the environment (Idowu and Rowland, 2006). Transmission takes place by direct contact with infected cattle but also indirectly through drinking water and eating fruits (Ortega et al., 1997). Fruits have nutritive values and are desirable, readily available by the road-sides and at major market places and as such, there is a great tendency to eat these fruits unwashed or improperly washed. Also the handling of fruits in market places allows for the transfer of parasites' infective stages to these fruits which are exposed for sight attraction, and even cut into pieces for affordability.

Regular consumption of fruits is associated with reduced risks of cancers, cardiovascular diseases (especially coronary heart disease), stroke, cataracts and some of the functional declines associated with aging (Halvosen et al., 2002). Diets that include a sufficient amount of potassium from fruits and vegetables also help to reduce the chance of developing kidney stones and the effect of bone loss (Halvosen et al., 2002). An important nutritional value of fruits is its antioxidant contents, fruits such as orange, carrot, garden egg and tomato have the highest antioxidant value which neutralizes free radicals which are harmful molecules that damage the body cells and cause inflammation (Halvosen et al., 2002).

The nutritional and health importance of fruits cannot be underestimated in that they contain substantial quantities of essential nutrients in a rational proportion. They are excellent sources of minerals, vitamins, enzymes and dietary fiber (Quebedeaux and Bliss, 1988). This study was therefore carried out to determine the prevalence of parasites of some fruits sold around Dutsin-ma, Nigeria and the risk of parasites' transmission via fruits and vegetables.

\section{MATERIALS AND METHODS \\ Study Area}

The study was conducted in Dutsin-ma Local Government Area of Katsina State. It is located on Latitude $12^{0} 27^{\prime} 18^{\prime \prime} \mathrm{N}$ and longitude $7^{0} 29^{\prime} 29^{\prime \prime} \mathrm{E}$ and has its headquarters in the town of Dutsin-ma. It has an estimated area of $527 \mathrm{~km}^{2}(203 \mathrm{sqkm})$ and a population of $1,169,671$ as at 2006 census(NIPOST 
Retrieved 2009-10-20). The Local Government is bounded by Kurfi and Charanchi Local Governments to the North, Kankia Local Government to the East, Safana and Dan- Musa Local
Governments to the South. The major occupation is farming and animal rearing, the inhabitant of the local Government are predominantly Hausa and Fulani (NPC, 2006).

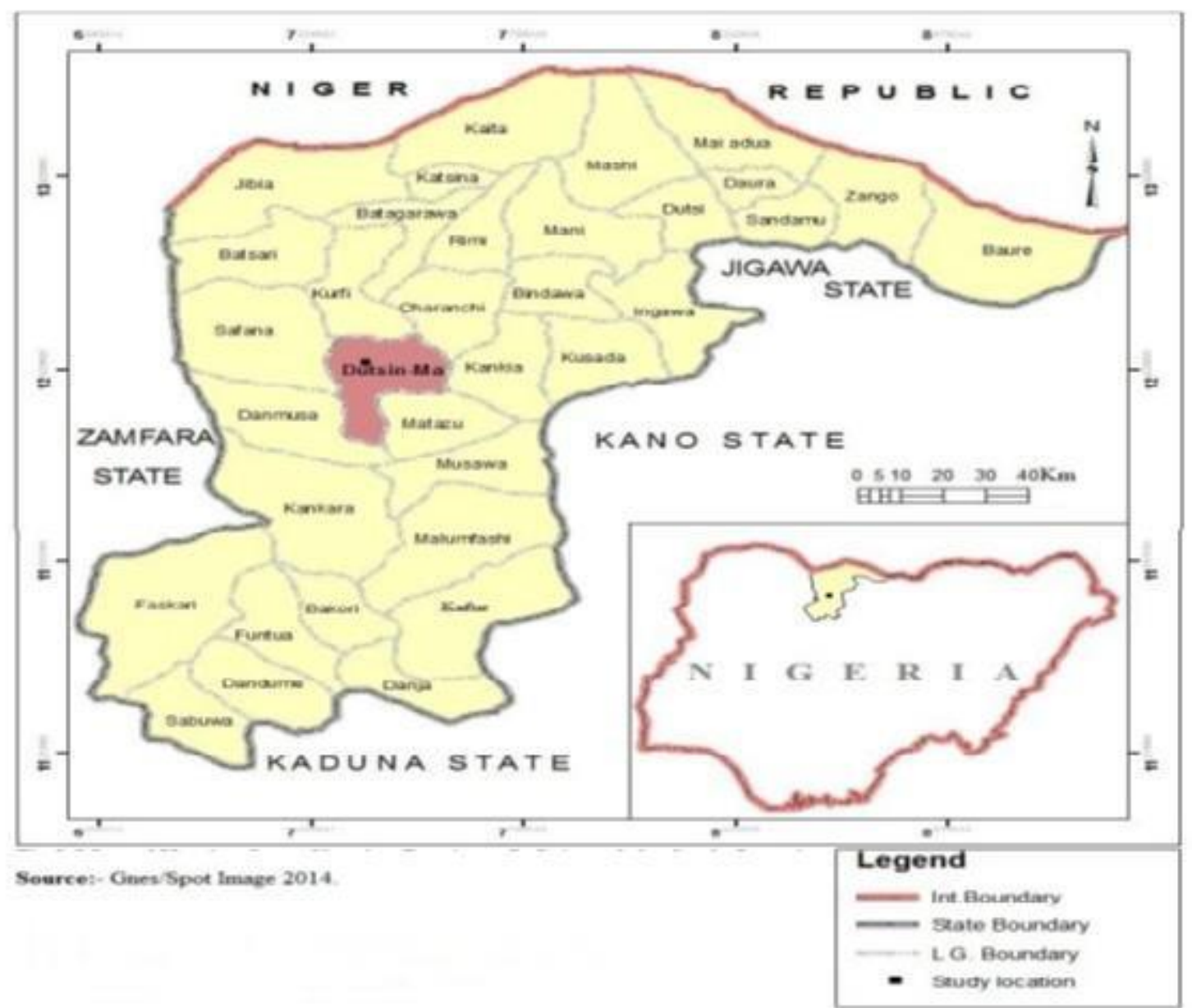

Fig 1: Map of Katsina showing Dutsinma Local Government Area

\section{Sample collection}

A total of 180 fruit pieces were bought from five vending sites $\mathrm{AB} 1, \mathrm{AB} 2, \mathrm{AB} 3, \mathrm{AB} 4$ and $\mathrm{AB} 5$ in Dutsin-ma metropolis where fruits were sold in large quantities on daily basis. The fruits bought included: garden egg (Solanum melongena), water melon (Citrullus lanatus), carrot (Daucus carota), orange (Citrus sinensis), cucumber (Cucumis sativus) and mango (Mangifera indica). The period of sample collection was peak of the rainy season. Each set of fruits was packaged into different sterile polythene bags, and transported to the Biological Sciences Laboratory of Federal University Dutsinma for examination.

\section{Laboratory examination of fruit samples}

Each fruit was washed with $100 \mathrm{ml}$ of distilled water into separate containers and the resultant liquids were allowed to stand for 20 minutes in appropriately labelled specimen bottles. The supernatants were then discarded and the sediments centrifuged for 5 minutes at 2,000 revolutions per minute (Fagbenro, 2016).
Wet smear preparation

The sediments were examined in drops under the light microscope.

\section{Floatation technique}

The water was filtered in a clean sieve to remove debris and large particles. It was centrifuged at 2,000 (rpm) rotation per minutes for 3 minutes and the supernatant was discarded. The sediment in each tube was filled to the brim with zinc sulphate which served as the floatation media and left for 30 minutes with a clean glass slide placed on the upper end of its meniscus (Fagbenro, 2016).

\section{Parasite identification and count}

A drop of oil immersion was placed on each slide and examined microscopically. Identification was carried out using standard guide as described by Arora and Arora (2005). 


\section{Data analysis}

The data was entered into the SPSS Spread Sheet 2010 which was used to determine significant variation in prevalence of the parasites in relation to the fruit types and vending sites. Descriptive statistics was used to get the mean and standard deviation. Chi-square test was used to determine association between fruits and infection

\section{RESULTS}

Some parasitic eggs, cysts and larva were observed in six parasites. Figure 2 including hook worm eggs Ascaris lumbricoideseggs, Trichuris trichuira eggs, Strongyloides stercoralis larvae, immature cyst of Entamoeba histolytica and eggs of Taenia species. The highest occurrence was recorded in the cysts of E.histolytica (31.62\%) followed by eggs of A.lumbricoides $(24.30 \%)$ and then the eggs of hookworm (16.42\%); eggs of Taenia spp. (12.4\%) and eggs of T.trichuira $(8.62 \%)$ while the least occurrence was recorded in the larva of S.stercoralis $(6.64 \%)$.

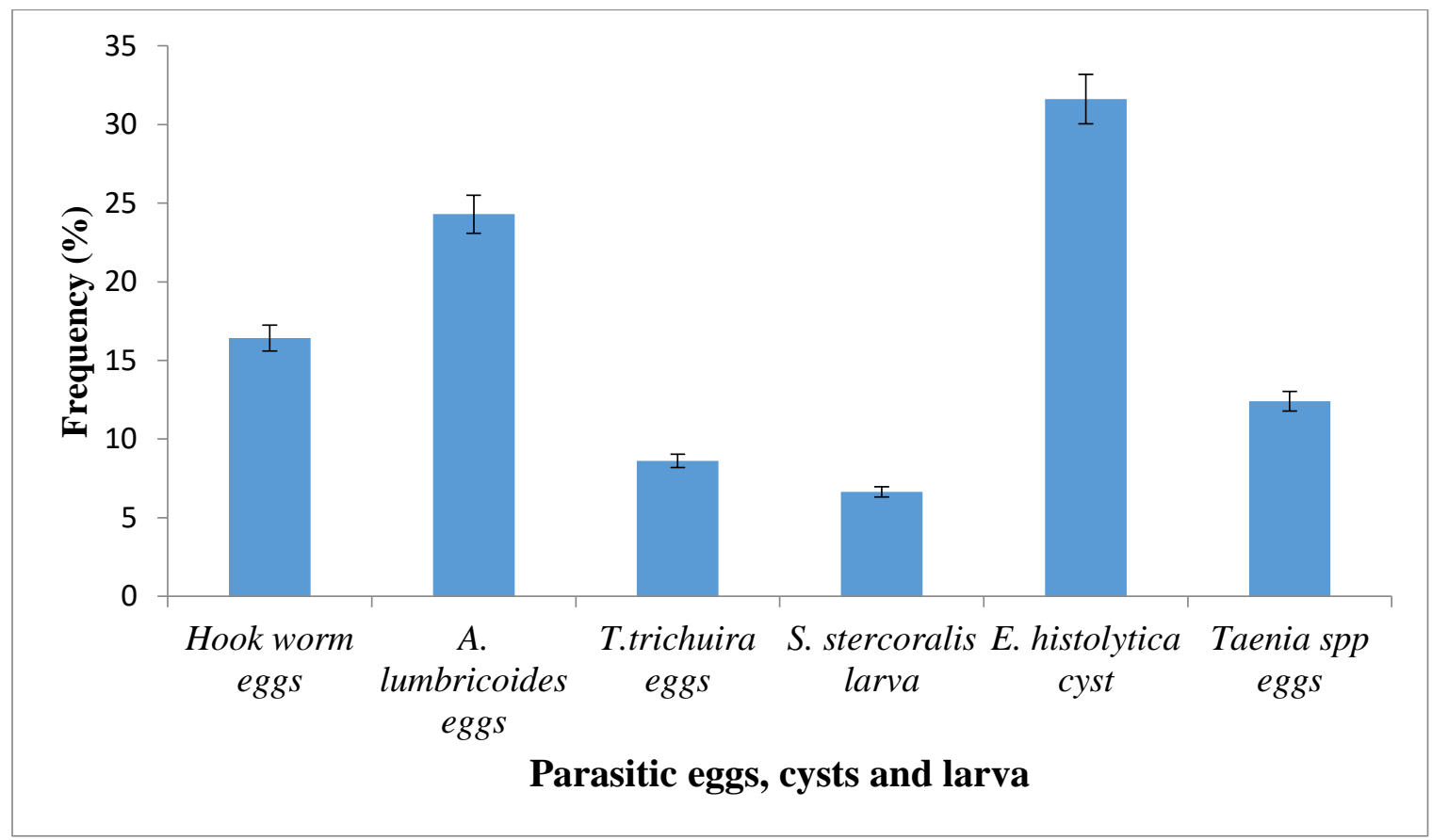

Fig 2: Occurrence of parasitic eggs, cysts and larva

The percentage of fruits with parasitic stages in Table 1 showed that garden egg recorded the highest prevalence of $60.3 \%$ followed by water melon $(21.4 \%)$, cucumber (12.12\%), mango (10\%); carrot showed $4.8 \%$ while orange showed no prevalence.

Table 1: Presence of parasitic eggs, cysts and larva in fruits around Dutsin-ma metropolis

\begin{tabular}{|c|c|c|c|}
\hline Fruit type & Number of fruits examined & $\begin{array}{l}\text { Number of fruits with } \\
\text { parasite }\end{array}$ & $\begin{array}{l}\text { Prevalence } \\
(\%)\end{array}$ \\
\hline Garden eggs & 36 & 12 & 60.3 \\
\hline Water melon & 28 & 6 & 21.4 \\
\hline Carrots & 41 & 2 & 4.8 \\
\hline Oranges & 12 & 0 & 0 \\
\hline Cucumber & 33 & 4 & 12.12 \\
\hline Mangoes & 30 & 3 & 10 \\
\hline Total & 180 & 27 & 15 \\
\hline
\end{tabular}

$\mathrm{X}^{2} \mathrm{cal}-5.26$ and $\mathrm{X}^{2}$ tab -11.07 at $\mathrm{p}=0.030$

The vending sites in Figure 3 showed that $\mathrm{AB} 3$ had the highest frequency in the different sites (52.33\%) followed by $\mathrm{AB} 1$ (38.35\%) then $\mathrm{AB} 5(32.33 \%)$ and $\mathrm{AB} 2(28.4 \%)$ while the least, $12.3 \%$ was from $\mathrm{AB} 4$ 


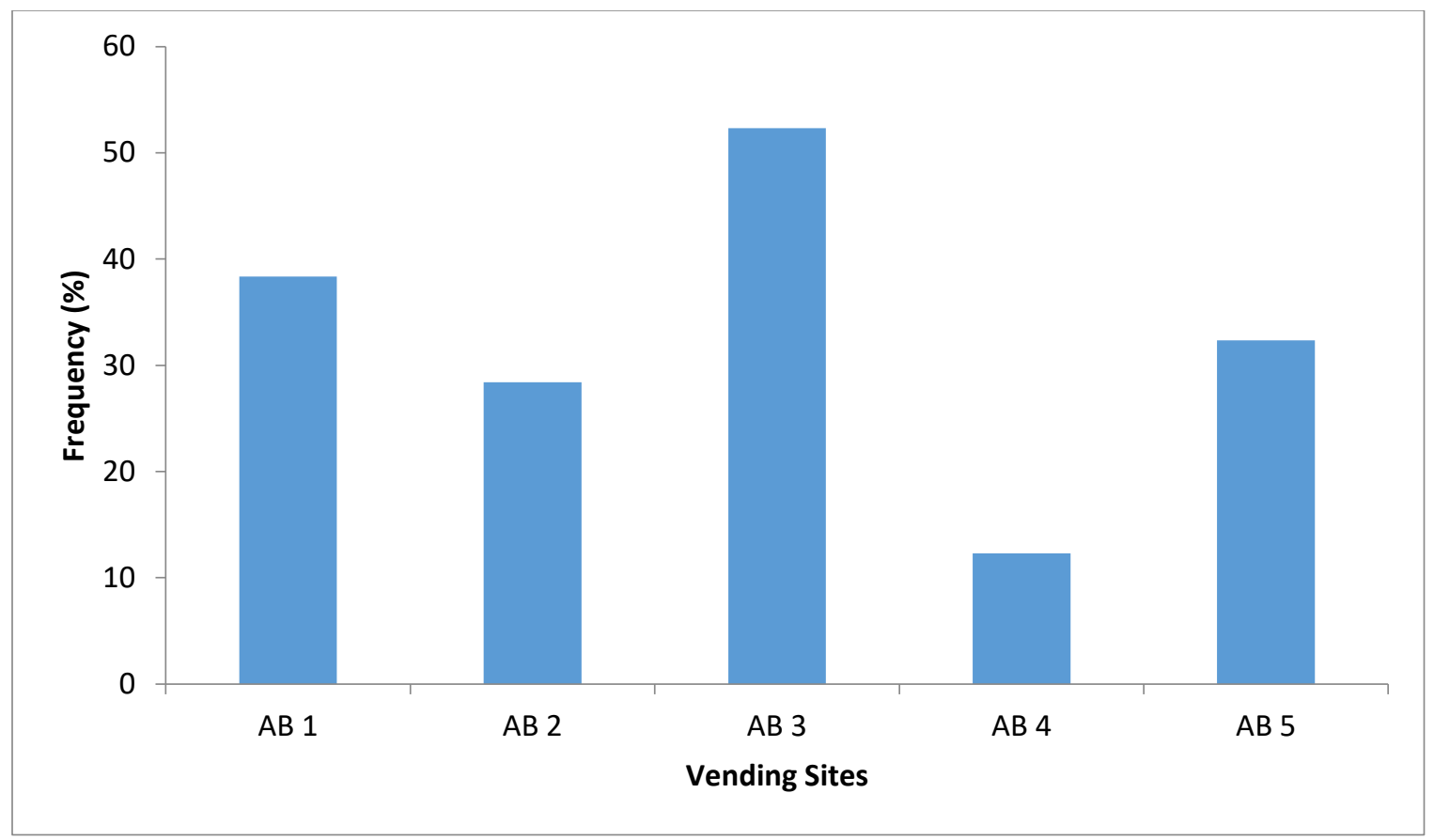

Fig 3: Occurrence of parasitic infection of fruits from sites $\mathrm{AB} 1, \mathrm{AB} 2, \mathrm{AB} 3, \mathrm{AB} 4$ and $\mathrm{AB} 5$

\section{DISCUSSION}

Fruits can become contaminated with microorganisms capable of causing human diseases while still on the plant in fields or orchards, or during harvesting, transport, processing, distribution and marketing, or in the home and are usually transmitted by contaminated water and spread by ineffective hygienic practice (Daryani, 2002). This study showed that fruits purchased from the five vending sites sampled contained intestinal parasite eggs, cysts and larva which are usually voided with faeces by humans and animals.

The source of acquisition of parasites' eggs, cysts or larva by the fruits examined from this research could be attributed to the usage of faecal matter as fertilizer which agrees with the studies of Uga et al. (2009) and untreated waste-water for irrigation purposes which also correlates with the work of Amoah, (2009) and Hassan et al. (2013).

A total overall prevalence of $15 \%$ of intestinal parasites on fruits reported in this study disagrees with the $36 \%$ reported by Damen et al. (2007) in Jos and the $48.48 \%$ reported by Hassan et al. (2013) in Ibadan; this could be due to period of investigation and the total number of samples collected which were all at variance and the season of the year. The period of investigation could also explain such differences in percentages in that the period of this study coincided with the wet season characterized with high amount of rain-water and decreased tendency of contamination by the parasites because of water availability.

Among the parasites identified in this study, E. histolytica cysts and A. Lumbricoides eggs were the most commonly encountered on fruits. This is in agreement with previous reports (Abougrain et al., 2009; Ekwunife and Akolisa, 2009; Alli et al., 2011 and Hassan et al., 2013). The reason could be because both parasites are connected with water and soil in most developing countries,

In this survey, percentage of the fruits sampled from the different vending sites showed that garden eggs and water melon recorded the highest agreeing with Hassan et al. (2013) who also reported the fruits as one of the most contaminated. The vending sites of $\mathrm{AB} 3$ and $\mathrm{AB} 1$ were noted as the most unhygienic sites that enhanced the risk of transmission of intestinal parasites to buyers while $\mathrm{AB} 4$ was the least. The reason for this could be due to poor storage and handling of the fruits by vendors of those sites. According to Saltveil, (1977), parasitic eggs and cysts can survive for a week or two or even a month depending on duration of storage of night soil and faecal-polluted water available for use by farmers and dealers in fruits.

In conclusion, the findings of this study are suggestive of parasitic stages present in the fruits an indication that consumers of raw fruits are at a high risk of intestinal parasitic infection. The relevance of fruit and vegetables in the diet cannot be over emphasized and so is the need for adequate enlightenment programmes at primary health care level to help reduce transmission and public health facilities should consider legislative actions towards improvement of production, storage and marketing of farm produce.

\section{REFERENCES}

Abougrain, A. K., Nataisi, M. H., Madi, N. S., Saied, M. M. and Ghenghesh, K. S. (2009). Parasitological contamination in salad vegetables in Tripoli-Libya.J.Foodcont.11.005.

Al-Binali, A.M., Bello, C. S., El-Shewy K., and Abdulla S. E., (2006).Theprevalence of parasites in commonly used leafy vegetables in South Western Saudi Arabia," Saudi Medical Journal,27(5) 613-616.

Alli, J. A., Abolade, G. O., Kolade, A. F., Salako, A. O., Mgbakor, C. J., Ogundele, M. T., Oyewo, A. J. and Agboola, M. O. (2011). Prevalence of intestinal parasites on fruits available in Ibadan markets, Oyo State, Nigeria. ActaParasitol.Globalis 2 (1): 06-10. 
Amoah, P. (2009). An analysis of the quality of waste-water used to irrigate vegetables in Accra, Kumasi and Tamale, Ghana. Int. Dev. Res. Center. 12: 41.

Amoah, P., Drechsel, P., Abaidoo, R. C. and Henseler, M. (2007).Irrigated urban vegetable production in Ghana: Microbiological contamination in farms and markets and associated consumer risk groups.J Water Hlth. 05(3): 455-465.

Arora, B. and Arora, D. R. 2005. Medical Parasitology.2nd Edition. CBSPublishers.ISBN 9788123911878. 243pp.

Carey, O. J., Cookson, J. B., Britton, J. and Tattersfield, A. E. (1996).The effect of lifestyle on wheeze, atopy, and bronchial hypersensitivity in Asian and white children.Am. J. Respir.and Critical Care Med. 153: 537-540.

Damen, J. G., Banwat, E. B., Egah, D. Z. and Allanana, J. A. (2007).Parasitic contamination of vegetables in Jos, Nigeria. Ann. Afri. Med. 6: 115-8.

Daryani, A. (2002). Prevalence of intestinal parasites in a healthy village in Ardabil City (Iran), before environmental sanitation. In: The 10th international congress of Parasitology, Vancouver, BC, Canada, Book of Abstract. 233pp.

Ekwunife, C. A. and Akolisa, I. C. (2009). Geo-helminth contamination of some common fruits and vegetables sold in Onitsha urban, south-east, Nigeria. The Zoologist. 7:96-101.

Erdogurul, O. R. and Sener, H. (2005). The contamination of various fruits and vegetables with Enterobiusvermicularis, Ascaris eggs, Entamoebahistolyticacysts.Food Control 16: $\quad$ 557-560.

Fagbenro, M. T., Mogaji, H. O., Oluwole, A. S., Adeniran, A. A., Alabi, O. M. and Ekpo, U. F. (2016). Prevalence of parasites found on vegetables, and perception of retailers and consumers about contamination in Abeokuta Area of Ogun State, Nigeria. Clinical Microbiology and Case Reports, 2(1): $1-5$.

Idowu, O. A. and Rowland, S. A. 2006.Oral faecal parasites and personal hygiene of food handlers in Abeokuta, Nigeria.Afri. Health Sci. 6:160-164.

Halvosen, B, Myhrstad M., Barikmo I, Hvattum E., Remberg S, Wold A., Haffnernk, Baugerod H., Andersen L., Moskaug J., Jacobs D., and Blohoff, R. (2002). Asystematic screening of total antioxidants in dietary plants.Journal of Nutrition; 132(3): 461-471.
Hassan, A.A., Ojuromi, O.T and Onyeahialam, O.(2013). Presenceof Parasitic Ova, Cysts and Larvae on common fresh fruits and vegetables sold at some major markets in Ibadan, Oyo State, Nigeria.The Zoologist, 11:40-45

Naish, S, McCarthy, J. and Williams, G. M. (2004).Prevalence, intensity and risk factors for soil-transmitted helminth infection in a South Indian fishing village.Acta Tropic. 91:177-87.

National Population Commission Census (2006). Federal republic of Nigeria official Gazette number 13 Nigeria: The Federal Government $.25 \mathrm{p}$.

Ortega, Y. R., Roxas, C. R., Gilman, R. H., Miller, N. J., Cabrera, L. and Taquiri, C. (1997). Isolation of Cryptosporidium parvum and Cyclosporacayetanensis from vegetables collected in markets of an endemic region in Peru. Am. J Trop Med. Hyg. 57: 683-686.

Saltveil, M. E. (1977). Physical and physiological changes in manually processed fruits and vegetables.Eds.TomasBaberan, F.A. and Robins, R. J. In: Phytochemistry of Fruits and Vegetables. Oxford Science, Oxford, U.K. pp. 205 -220.

Quebedeaux, B. and Bliss F. A. (1988). Horticulture and human health.Contribution of fruits and vegetable.Proc. $1^{\text {st }}$ Intl. SympHort.And human Health.Prentice Hall, Englewood NJ.

Thaddeus, K, Graczyk, R. K. and Leena, T. (2005).Mechanical transmission of human protozoan parasites by insects.ClinMicrobiol Rev. 18(1): 128-132.

Uga, S., Hoa, N. T., Noda, S., Moji, K., Cong, L., Aoki, Y., Rai, S. K. and Fujimaki, Y. (2009). Parasite egg contamination of vegetables from a suburban market in Hanoi, Vietnam. Nepal Med. Coll J. 11: 75-78.

Uneke, C.J. (2007). Potential for geohelminth parasite transmission by raw fruits and vegetables in Nigeria: Implication for a risk profile. J.Nutri.Environ. Med. 16:59- 68.

(C)2020 This is an Open Access article distributed under the terms of the Creative Commons Attribution 4.0 International license viewed via https://creativecommons.org/licenses/by/4.0/ which permits unrestricted use, distribution, and reproduction in any medium, provided the original work is cited 